\title{
Effect of aqueous rosemary extract on some sexual hormones in male rats with high thyroxine level
}

\author{
F.Z. Hamzah ${ }^{1}$, N.M. Al-Sharafi ${ }^{1}$, S.F. Kasim ${ }^{2} \odot$ \\ ${ }^{1}$ College of Veterinary Medicine, University of Kufa, Kufa, ${ }^{2}$ College of Health and Medical Technology, Middle Technical \\ University, Baghdad, Iraq
}

\begin{tabular}{l} 
Article information \\
\hline Article history: \\
Received March 31, 2020 \\
Accepted May 15, 2020 \\
Available online March 15, 2021 \\
\hline Keywords: \\
Testosterone \\
FSH \\
LH \\
Levothyroxine \\
Herbs \\
\hline Correspondence: \\
S.F. Kasim \\
sumayah.faruq@,mtu.edu.iq
\end{tabular}

\begin{abstract}
The main purpose of this research is to evaluate the high level of thyroxine affects on each of the luteinizing hormone ( $\mathrm{LH})$, testosterone, follicle-stimulating hormone (FSH) of rats and to estimate the potential effect of the administration of aqueous rosemary extract and propylthiouracil against testicular toxicity induced by levothyroxine in male rats. Negative control group rats were treated with distilled water. Three groups of male rats were treated subcutaneously with $0.5 \mathrm{mg} / \mathrm{kg}$ levothyroxine for 12 days: Since day $13^{\text {th }}$ to the $24^{\text {th }}$ day of the experiment first group was regarded as a positive control group that received distilled water, the second group was given propylthiouracil at a dose level of $10 \mathrm{mg} / \mathrm{kg}$ b.wt, and the third was given aqueous extracts of rosemary $10 \mathrm{mg} / \mathrm{kg} \mathrm{b}$.wt. The results revealed that treatment with aqueous extract of rosemary lead to a significant decrease in the levels of serum testosterone while a highly significant decrease in testosterone, FSH, and LH levels in serum revealed after treatment with propylthiouracil. Thus, it can be concluded that the effect of propylthiouracil and rosemary aqueous extract resulted in dialectical hormonal results in which the favor was to propylthiouracil.
\end{abstract}

DOI: $10.33899 /$ ijvs.2020.126872.1404, (C2021, College of Veterinary Medicine, University of Mosul.

This is an open access article under the CC BY 4.0 license (http://creativecommons.org/licenses/by/4.0/).

\section{Introduction}

Levothyroxine (LT4), synthetic thyroxine administrated orally, is the favorable treatment for patients with hypothyroidism. Moreover, it could be administered for the repression of pituitary production of thyroid-stimulating hormone in cases of not poisonous multinodular goiter and diverse forms of neoplasia in thyroid (1). However, Levothyroxine has a limit curative index, subjected patients to the risk of iatrogenic hyper- or hypothyroidism at dosage just $25 \%$ more than normal, or that are more than the most favorable dose, depending on patients' serum level of TSH (2). Data from many investigations showed that Levothyroxine induce hyperthyroidism "high level of thyroxine" in male rats at $0.5 \mathrm{mg} / \mathrm{kg}$ i.p or subcutaneously for successive 12 days $(3,4)$.

Testosterone is the major secretive production of the testis, besides the 5a-dihydrotestosterone (DHT), 17- hydroxyprogesterone, progesterone, pregnenolone, androsterone, and androstenedione $(5,6)$. testosterone is a first-rate endocrine agent, a piece of evidence available as a local organizer of spermatogenesis (7). Also, it is testosterone that determines the former phase of testicular migration and the growth of male exterior genitalia (8). FSH and $\mathrm{LH}$ are hormones of glycoprotein secreted from the pituitary gland which regulate growth, maturation, and roles of the gonad (9).

Rosemary (Rosmarinus officinalis L.) (general name, rosemary; family Labiatae), is a common domestic herb grown in abundant parts of the world. It is used for cosmetics, flavouring food, and as a drink (10-12). Rosemary is known to be a rich origin of effective metabolites (13) and is used in popular medicines (14). Archaeologists and anthropologists have found proof that herbs of rosemary have been used as a medical herb, culinary in cooking and for beauty in Mesopotamia, ancient Egypt, India and China 
(15). Rosemary officinalis enhanced the immunity (16), and considered as an antimutagenic agent (17). Internal use of rosemary for dyspeptic troubles and external use for rheumatic cases and hypotonic-circulatory disorders. As well it is used in conventional medicine for migraine, headache, digestive symptoms, amenorrhea, dysmenorrhea, oligomenorrhea, states of exhaustion, poor memory, and dizziness. Externally, it is used for poorly healing wounds as a poultice, also in eczema, for injuries of the mouth and throat as an analgesic, for myalgias used topically, intercostal sciatica and neuralgia. However, it must not be used throughout the pregnancy period. There were no side effects or health prohibitions are known in synchronism with the suitable administration of fixed curative doses. Allergies have been noticed on occasions. Extremely large amounts of rosemary leave misapplied for the abortion, which could lead to spasm, gastroenteritis, vomiting, kidney irritation, uterine bleeding, deep coma and death in humans (18). This study showed the effect of both and rosemary (Rosmarinus officinalis) and Propylthiouracilon serum of luteinizing hormone, testosterone, follicle-stimulating hormone levels with experimental hyperthyroidism.

\section{Materials and methods}

\section{Chemicals}

L-Thyroxine (T4), propylthiouracil (PTU) taken up from Sigma Chemical Co., USA. The testosterone, FSH, LH and T4 hormones were managed by using commercially available kits supplied by Calbiotech Inc., USA.

\section{Preparation of extracts}

Dried leaves of Rosemary were purchased from a local supermarket in Kufa, Iraq. the leaves were grind and store in the dark. Briefly, we made the extract by stirring of powder $10 \mathrm{~g} / 100 \mathrm{ml}$ in distilled water for 30 minutes at $50{ }^{\circ} \mathrm{C}$ succeeded by fast refinement throughout a rough piece of cloth, then, through the refinery sheet. The definitive nominate was freeze-dried (lyophilized) and thereafter applied in the experiment (19).

\section{Experimental animal design}

Twenty-four male albino rats 170-200 gram weight were housed in the animal house under the steady status of temperature $24 \pm 2^{\circ} \mathrm{C}$ for three weeks prior to the beginning of the experiment, the animal house under laboratory conditions 12/12 hours light - dark cycle $(20,21)$ and being preserved on a standard water and diet ad libitium $(22,23)$. The animals were treated according to the specific guidelines of the veterinary medicine faculty and the study was approved by the Animal Ethics Committee of the University of Kufa. The experimental rats were divided as the following (in which every group has six rats). Group 1 animals were received $0.1 \mathrm{ml} /$ day distilled water orally by gavage and considered as negative control group. Group 2 animals were treated subcutaneously for successive 12 days with Levothyroxine $0.5 \mathrm{mg} / \mathrm{kg}$. From the $13^{\text {th }}$ to $24^{\text {th }}$ day the animals were received $0.1 \mathrm{ml} /$ day distilled water by gavage orally in which considered positive control group. Group 3 animals were treated subcutaneously for successive 12 days with Levothyroxine $0.5 \mathrm{mg} / \mathrm{kg}$. From the $13^{\text {th }}$ to $24^{\text {th }}$ day the animals were received $10 \mathrm{mg} / \mathrm{kg}$ propylthiouracil orally by gavage. Group 4 animals were treated subcutaneously for successive 12 days with Levothyroxine $0.5 \mathrm{mg} / \mathrm{kg}$. From the $13^{\text {th }}$ to $24^{\text {th }}$ day the animals were received $10 \mathrm{mg} / \mathrm{kg}$ aqueous leaves extract of rosemary (Rosemarinus officinalis) orally by gavage.

\section{Blood collecting}

At the end of the experiment, all rats were subjected to light ether anesthesia, then sacrificed for the collection of blood, then serum separation was performed for thyroxine hormone to confirm the state of hyperthyroidism, serum testosterone level, serum follicle stimulating hormone level, and serum luteinizing hormone level.

\section{Statistical analysis}

The data were subjected to analysis of variance and the significance differences at $\mathrm{P} \leq 0.05$ which were determined by analysis of variance (ANOVA), one-way by using the statistical soft ware's sigma statistical (24).

\section{Results}

T4 level had significantly increased in positive-control group as compared with the negative-control group as presented in (Table 1). Data in Table 2 showed that levels of serum testosterone, LH and FSH were significantly increased in the positive-control group as compared with the negative-control group. The serum testosterone level of the experimental groups was significantly decreased in PTU treated group while highly significant decreased in aqueous rosemary extract treated group in comparison with the negative control group. Serum levels of LH and FSH in the experimental groups were significantly decreased in PTU treated group while significantly increased in aqueous rosemary extract treated group as compared with the negative-control group, in other words there were insignificance differences between the LH and FSH serum levels in rosemary treated group and positive-control group.

Table 1: Effect of Levothyroxine on serum thyroxine in male rats

\begin{tabular}{lc}
\hline & Thyroxine $(\mathrm{T} 4) \mu \mathrm{g} / \mathrm{dl}(\mathrm{Mean} \pm \mathrm{SE})$ \\
\hline Negative & $58.91 \pm 2.22 \mathrm{~B}$ \\
control & $76.74 \pm 1.93 \mathrm{~A}$ \\
Positive control & 8.279 \\
LSD &
\end{tabular}

Capital letters denote differences between groups, $\mathrm{P}<0.05$. 
Iraqi Journal of Veterinary Sciences, Vol. 35, No. 2, 2021 (369-373)

Table 2: Effect of aqueous rosemary extract and PTU on LH, testosterone, and FSH in male rats with a high level of thyroxine induced by levothyroxine

\begin{tabular}{lccc}
\hline & & Mean \pm SE & \\
\cline { 2 - 4 } & Testosterone $(\mathrm{ng} / \mathrm{dl})$ & FSH $(\mathrm{mul} / \mathrm{ml})$ & $\mathrm{LH}(\mathrm{mul} / \mathrm{ml})$ \\
\hline Negative control & $0.715 \pm 0.027 \mathrm{C}$ & $0.897 \pm 0.011 \mathrm{~B}$ & $0.724 \pm 0.024 \mathrm{~B}$ \\
Positive control & $4.950 \pm 0.371 \mathrm{~A}$ & $0.975 \pm 0.008 \mathrm{~A}$ & $0.903 \pm 0.038 \mathrm{~A}$ \\
PTU & $0.095 \pm 0.013 \mathrm{D}$ & $0.756 \pm 0.017 \mathrm{C}$ & $0.644 \pm 0.012 \mathrm{C}$ \\
Rosemary & $3.497 \pm 0.146 \mathrm{~B}$ & $0.965 \pm 0.012 \mathrm{~A}$ & $0.830 \pm 0.004 \mathrm{~A}$ \\
LSD & 0.616498 & 0.039409 & 0.0739415 \\
\hline
\end{tabular}

Capital letters denote differences between groups, $\mathrm{P}<0.05$.

\section{Discussion}

In this experimental project, we found that propylthiouracil administration decreased serum testosterone, LH and FSH levels which seem to have more effective role than rosemary in comparison their data with untreated control group. This is definitely related with role of PTU in deceasing T4 level and limited the side effect of high level of thyroxine represented with raise serum level of LH and FSH. Hyperthyroidism is related to main changes in testosterone metabolism, the harmonious findings have been determined that the $\mathrm{LH}$ and FSH level responses to gonadotropin-releasing hormone $(\mathrm{GnRH})$ administration are increased in men hyperthyroidism (25). This oddity of the hypothalamic-pituitary-gonadal axis correlates with the concentrations of serum T4 and regain the normal correction of the hyperthyroidism by treatment with thyroid hormone inhibitors as the use of PTU in our study. The concentration of sex hormone-binding globulin (SHBG) in serum or plasma is increased (26) that is associated with the rise in total testosterone level (27). The changes in the concentration of total testosterone resulted in a studied blood outcome rate for testosterone in patients with hyperthyroidism that is not significantly diverse from normal individuals (28). Though the abnormalities of the hypothalamic-pituitary testicular-axis have been authenticated in thyrotoxicosis (29), unequivocal clinical proof of hypo or hyperandrogenic is generally not found.

On the other hand, the role of rosemary might be contributed to the various constituents of it. Rosemary consists abundant of biologically active components; including antioxidants items rosmarinic acid, carnosic acid, betulinic acid, ursolic acid, rosmanol, and rosmaridiphenol. Thus, rosemary extract appears as a cytoprotective factor when exposed to the free radical scavenging activity which leads to widespread damage to cellular compounds as membrane lipids and highly raised the normal cell viability and the activity of antioxidant enzymes GSH and SOD and significantly decreases MDA contents (30). Rosemary extract is able to donate electrons to reactive radicals, altered them to more stabilized and on reactive kinds, subsequently preventing them from coming biomolecules for instance polyunsaturated fatty acids, lipoproteins, amino acids, DNA, proteins, and sugars, in liable biological systems (31).

The rosemarnic acid and phenolic compounds were believed to be the most significant constitutes of rosemary, which identified by their anti-free radical's activity, these constituents are fully absorbed from the skin and gastrointestinal tract. (32). There are several vital actions of rosemary leaves, like reluctance to all types of cancers, infections, bacteria, and its antioxidant activity for the existence of caffeic acid and its derivatives. The vital actions of leaves extract of rosemary are corresponding with known anti-oxidants components, such as rosemarenic, arnosic, carnasol, ursolic acids, butylated hydroxytoluene, and butylated hydroxyanisole, without ally hazard to carcinogenic or the cytotoxicity of the artificial antioxidants (33-35). In the present work, the administration of rosemary leaves aqueous extract after high level of thyroxine induced by levothyroxine had a poor effect on testosterone serum level which is firmly due to the low dose of rosemary extract $10 \mathrm{mg} / \mathrm{kg} \mathrm{b}$.w, whereas the favor was to the propylthiouracil.

\section{Conclusion}

Although the poor effect of rosemary leaves extract on serum testosterone, we must as well be mindful of its ameliorative effects if utilized in higher dosage. Thus, further studies must be done in the future.

\section{Acknowledgments}

We like to express our gratitude and acknowledge the precious help to Prof. Dr. Ali Faruq Kasim for providing all the possible facilities in the statistical analysis.

\section{Conflicts of interest}

No conflicts.

\section{References}

1. Helfand M, Crapo LM. Monitoring therapy in patients taking levothyroxine. Ann Intern Med. 1990;113(6):450-454. Doi: $\underline{10.7326 / 0003-4819-113-6-450}$ 
2. Carr D, McLeod DT, Parry G, Thomes HM. Fine adjustment of thyroxine replacement dosage: Comparison of the thyrotropin releasing hormone test using a sensitive thyrotropin assay with measurement of free thyroid hormones and clinical assessment. Clin Endocrinol. 1988;28(3):325-333. Doi: 10.1111/j.1365-2265.1988.tb01219.x

3. Panda S and Kar A. Annona squamosa seed extract in the regulation of hyperthyroidism and lipid-peroxidation in mice: possible involvement of quercetin. Phytomed. 2007;14(12):799-805. Doi:10.1016/j.phymed.2006.12.001

4. Panda S and Kar A. Antithyroid effects of naringin, hesperidin and rutin in 1-T4 induced hyperthyroid rats: Possible mediation through $5^{\prime}$ DI activity. Pharmacol Report. 2014;66(6):1092-1099. Doi: 10.1016/j.pharep.2014.07.002

5. Luetjens CM, Didolkar A, Kliesch S, Paulus W, Jeibmann A, Böcker W, Nieschlag E, Simoni M. Tissue expression of the nuclear progesterone receptor in male non-human primates and men. $\mathrm{J}$ Endocrinol. 2006;189(3):529-539. Doi: 10.1677/joe.1.06348

6. Modi DN, Shah C, Puri CP. Non-genomic membrane progesterone receptors on human spermatozoa. Soc Reprod Fertil Suppl. 2007;63:515-529. [available here]

7. Takaimya K, Yamamoto A, Furukawa K, Zhao J, Fukumoto S, Amashiro S, Okada M, Haraguchi M, Shin M, Kishikawa M, Shiku H, Auzawa S, Furukawa K. Complex gangliosides are essential in spermatogenesis of mice: possible roles in the transport of testosterone. Proc Natl Acad Sci. 1998;95(21):12147-12152. Doi: 10.1073/pnas.95.21.12147

8. Huhtaniemi I, Jiang M, Nilsson C, Petterson K. Mutations and polymorphisms in gonadotropin genes. Mol Cell Endocrinol. 1999;151(1-2):89-94. Doi: 10.1016/s0303-7207(99)00015-5

9. Weinbauer GF, Luetjens CM, Simoni M, Nieschlag E. Physiology of Testicular Function. Androl. 2010;11-59. Doi: 10.1007/978-3-54078355-8 2

10. Gilani AH, Rahman AU. Trends in ethnopharmacology. J Ethnopharmacol. 2005;100(1-2):43-49. Doi: 10.1016/j.jep.2005.06.001

11. Lohiya NK, Goyal RB, Jayaprakash D, Ansari AS, Sharma S. Antifertility effects of aqueous extract of Carica papaya seeds in male rats. Planta Med. 2005;60(05):400-404. Doi: 10.1055/s-2006-959518

12. Fitter JT, Thomas MR, Niu C, Rose RJ. Investigation of Nicotianatabacum(+) N. suaveolenscybrids with carpelloid stamens. J Plant Physiol. 2005;162(2):225-235. Doi: 10.1016/j.jplph.2004.02.006

13. Karamanoli K, Vokou D, Menkissoglu U, Constantinidou, IH. Bacterial colonization of phyllosphere of Mediterranean aromatic plants. J Chem Ecol. 2000;26, 2035-2048. Doi: 10.1023/A:1005556013314

14. Al-Sereiti M R, Abu-Amer K M, Sen P. Pharmacology of Rosemary (Rosmarinus officinalis Linn.) and its therapeutic potentials. Int J Exp Biol. 1999;37(2):124-130. [available here]

15. Stefanovits-Bányai E, Tulok M, Hegedûs A, Renner C,Szöllôsi VI. Antioxidant effect of various rosemary (Rosmarinus officinalis L.) clones. Acta Biol Szegediensis. 2003;47(1-4):111-113. [available here]

16. Ibrahim R M. Effect of aqueous extract of Rosemary officinalis on cytotoxicity of $\mathrm{CCL}_{4}$ induced albino male mice. J Biotechnol Res Center. 2018;12(1):124-131. [available here]

17. Abdul AA, Al-A'adhmi M A, Al-Awadi B Q. The inhibition of genotoxicity effect of Methotrexate(MTX) in human lymphocyte in vitro using aqueous extract of Rosmarinus officinalis. JBiotechnol Res Cent. 2014;8(4):53-56. [available here]

18. Gruenwald J, Brendler T, Jaenicke C, Mehta M. PDR for Herbal Medicines. Medical Economics Company. 2000;645-646. [available here]

19. Amin A and Hamza A. Hepatoprotective effects of Hibiscus, Rosmarinus and Salvia on azathioprine-induced toxicity in rats. Life Sci. 2005;77(3):266-278. Doi: $10.1016 / j .1 f s .2004 .09 .048$

20. Mustafa K.A. and Al-Baggou BK. Toxicological and neurobehavioral effects of chlorpyrifos and deltamethrin insecticides in mice. Iraqi J Vet Sci. 2020;34(1):189-196. Doi: 10.33899/ijvs.2019.125738.1144
21. Ismail H.Kh., Al-Sabawy R.A., Jumaa H.J. Protective effect of placental mesenchymal stem cells on histological changes of pancreas experimentally induced by alloxane in mice. Iraqi $\mathrm{J}$ Vet Sci. 2020;34(1):1-8. Doi: 10.33899/ijvs.2020.163563

22. Jameel A.H., Mohammed M.J., Mahdi M.S., Thalj K.M. Physiological effects of lactic acid bacteria against melamine induced toxicity in female albino rats. Iraqi J Vet Sci. 2021;35(1):1-7. Doi: 10.33899/ijvs.2020.126183.1259

23. Al-Allaf L.I. and Al-Ashoo H.A. A histological study on the effect of imatinib on the rats' testis after early postnatal exposure. Iraqi J Vet Sci. 2021;35(1):85-92. Doi: 10.33899/ijvs.2020.126342.1303

24. Statistical Packages for the Social Sciences (SPSS). Statistical software for windows version 19.0 Microsoft. 2010 SPSS, Chicago, Illinois, USA. [available here]

25. Zahringer S, Tomova A, von Werder K, Brabant G, Ku- manov P, Schopohl J. The influence of hyperthyroidism on the hypothalamicpituitary-gonadal axis. Exp Clin Endocrinol Diab. 2000;108(04):282289. Doi: $10.1055 / \mathrm{s}-2000-7756$

26. Anderson. DC. Sex-hormone-binding globulin. Clin Endocrinol. 1974;3:69-96.

27. Loric S, Duron F, Guechot J, Aubert P, Giboudeau J. Testosterone and its binding in hyperthyroid women before and under antithyroid drug therapy. Aria Endocrinol. 1989;121(3):443-446. Doi: 10.1530/acta.0.1210443

28. Ridgway EC, Maloof F, Longcope C. Androgen and oestrogen dynamics in hyperthyroidism. J Endocrinol. 1982;95(1):105-115. Doi: 10.1677/joe.0.0950105

29. Kidd, GS, Glass AR, Vigersky RA. The hypothalamicpituitarytesticular axis in thyrotoxicosis. J Clin Endocrinol Meiabol. 1979;48(5):798-802. Doi: 10.1210/jcem-48-5-798

30. Labban PL, Mustafa UE, Ibrahim YM. The effects of rosemary (Rosmarinus officinalis) leaves powder on glucose level, lipid profile and lipid. Int J Clin Med. 2014;5(6):297-304. Doi: 10.4236/ijcm.2014.56044

31. Sak SA, Lamfon HA. Protective Effect of rosemary (Rosmarinus officinalis) leaves extract on carbon tetrachloride -induced nephrotoxicity in albino rats. Life Sci J. 2012;9:779-785. [available here]

32. Singletary K, MacDonald C, Wallig M. Inhibition by rosemary and carnosol of 7, 12 dimethylbenz(a) anthracene (DMBA)-induced rat mammary tumorigenesis and in vivo DMBA-DNA adduct formation. Cancer Lett. 1996;104(1):43-48. Doi: 10.1016/0304-3835(96)04227-9

33. Hussain AI, Anwar F, Chatha SAS, Jabbar A, Mahboob S, Nigam PS. Rosmarinus officinalis essential oil: antiproliferative, antioxidant and antibacterial activities. Braz J Microbiol. 2010;41(4):10701078. Doi: $10.1590 / \mathrm{s} 1517-83822010000400027$

34. Altinier G, Sosa S, Aquino RP, Mencherini T, Della Loggia R, Tubaro A. Characterization of topical anti-inflammatory compounds in Rosmarinus officinalis L. J. Agric. Food Chem. 2007;55:1718-1723. Doi: $10.1021 / \mathrm{jf} 062610$

35. Sheen CL, Dillon JF, Bateman DN, Simpson KJ, Macdonald TM. Paracetamol toxicity: Epidemiology, prevention and costs to the healthcare system. QJM. 2002;95:609-619. Doi: 10.1093/qjmed/95.9.609 
بو اسطة الليفوثيروكسين في ذكور الجرذان. تم معاملة جرذان المجموعة المانة

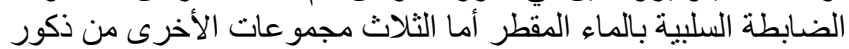

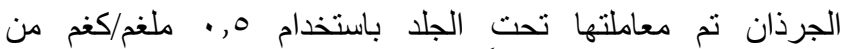

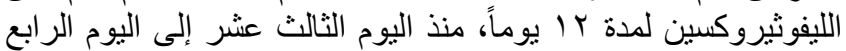

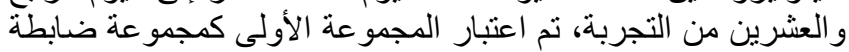

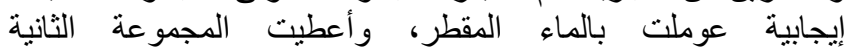

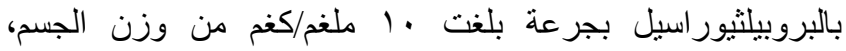

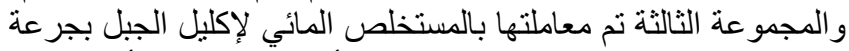

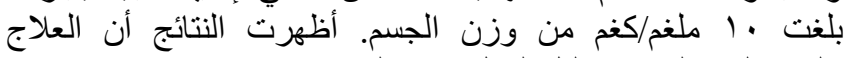

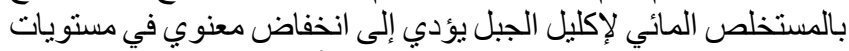

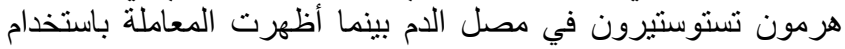

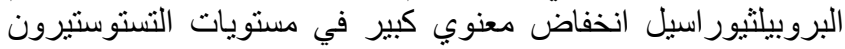

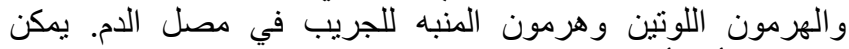

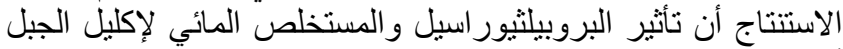

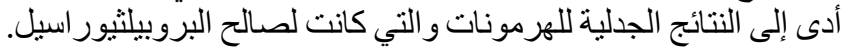

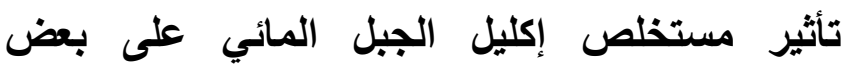
الهرمونات الجنسية في ذكور الجرذان ذات المئين المستوى

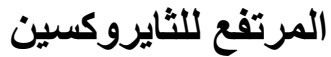

فؤاد زيدان حمة'، ،بيل محمد ناجي الثريفي' و سميه فاروق قاسم'

'كلية الطب البيطري، جامعة الكوفة، الكوفة، 'كلية التقنيات الصحية

و الطبية، الجامعة التقنية الوسطى، بغداد، العراق الكرة

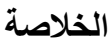

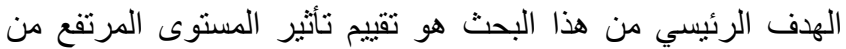

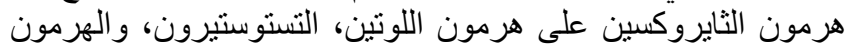

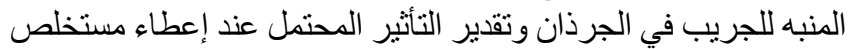

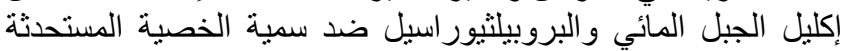

